\title{
Black-Tailed Prairie Dog Effects on Montana's Mixed-Grass Prairie
}

\author{
Carolyn M. Johnson-Nistler, ${ }^{1}$ Bok F. Sowell, ${ }^{2}$ \\ Harrie W. Sherwood, ${ }^{3}$ and Carl L. Wambolt ${ }^{4}$ \\ Authors are ${ }^{1}$ Associate Wildlife Specialist, ${ }^{2}$ Associate Professor, ${ }^{3}$ Research Associate, and ${ }^{4}$ Professor, \\ Animal and Range Sciences Department, Montana State University, Bozeman, MT 59717. \\ At the time of research, Johnson-Nistler was Research Assistant, \\ Animal and Range Sciences Department, Montana State University, Bozeman, MT.
}

\begin{abstract}
Forty paired sites were examined on the mixed-grass prairie of northeastern Montana to compare the effects of black-tailed prairie dog (Cynomys ludovicianus) colonies on native range vegetation. Thirty $0.25-\mathrm{m}^{2}$ quadrats were placed on colonized and uncolonized locations and matched by environmental conditions. Cover and standing crop biomass of each plant species was estimated using a double sampling procedure where every third plot was clipped and estimated. A total of 2400 quadrats were estimated, whereas 720 quadrats were clipped during the months of May-August of 2000 and 2001. Crude protein, digestibility, neutral detergent fiber, and acid detergent fiber were determined on the basis of vegetative classes (cool-season grasses, warmseason grasses, standing dead grass, forbs, and dwarf shrubs). Pairwise comparisons were made using paired $t$ tests and differences were declared significant at the 0.05 level. Plant biomass of colonized sites was dominated by fringed sagewort (Artemisia frigida Willd.) (42\%), blue grama (Bouteloua gracilis [HBK] Lag. ex Steud) (16\%), and western wheatgrass (Agropyron smithii Rydb.) $(16 \%)$. Uncolonized sites were dominated by Wyoming big sagebrush (Artemisia tridentata ssp. wyomingensis Beetle and Young) $(36 \%)$, western wheatgrass $(13 \%)$, and blue grama $(12 \%)$. Standing crop biomass, plant species richness, litter, standing crop crude protein, sagebrush canopy cover, and density were greater $(P<0.05)$ on uncolonized areas compared to colonized areas. Bare ground and crude protein concentration were greater $(P<0.05)$ on areas colonized by prairie dogs compared to uncolonized areas. Digestibility and fiber content of both areas were not different $(P>0.05)$. Activities associated with prairie dog colonies reduced plant productivity and plant species richness of the mixed-grass prairie by reducing cool-season perennial grasses and litter, increasing bare ground, and eliminating big sagebrush.
\end{abstract}

\section{Resumen}

Se examinaron 40 sitios apareados ubicados en un pastizal de zacates mixtos del nordeste de Montana para comparar los efectos de las colonias de perrito de la pradera (Cynomys ludovicianus) en la vegetación nativa del pastizal. Se colocaron 30 cuadrantes de $0.25 \mathrm{~m}^{2}$ en áreas colonizadas y sin colonizar apareadas con las condiciones ambientales. La cobertura y biomasa en pie de cada especie de planta se estimaron usando el procedimiento de doble muestreo en el que cada tercer parcela se cortó y se midieron las características de interés. Se estimaron un total de 2,400 cuadrantes, de los que 720 fueron cortados durante los meses de Mayo a Agosto del 2000 y 2001. Se determinó el contenido de proteína cruda, FND, FAD y la digestibilidad en base a clases vegetativas (zacates de estación fría, zacates e estación caliente, biomasa en pie muerta de zacates hierbas y arbustos pequepos). El análisis de los datos se llevo a cabo mediante pruebas de $t$-student para medias apareadas y se estableció un nivel de significancia de 0.05 . La biomasa vegetal de los sitios colonizados estuvo dominada por "fringed sagewort" (Artemisia frigida Willd.) (42\%), "Blue grama" (Bouteloua gracilis HBK lag ex Steud) (16\%) y "Western wheatgrass" (Agropyron smithii Rydb.) (16\%). Los sitios sin colonizar estuvieron dominados por "Wyoming big sagebrush" (Artemisia Nutt. Ssp. Wyomingensis) (36\%), "Western wheatgrass" (13\%) y "Blue grama" (12\%). La biomasa en pie, la riqueza de especies vegetales, el mantillo, el contenido de proteína cruda y la cobertura y densidad del "Sagebrush" fueron superiores $(P<0.05)$ en las áreas sin colonizar que en las áreas colonizadas. La concentración de proteína cruda y el porcentaje de suelo desnudo fueron mayores $(P<0.05)$ en las áreas colonizadas por los perritos de la pradera que en las áreas sin colonizar. El contenido de fibra y la digestibilidad no difirió entre ambas áreas $(P<$ 0.05 ). Las actividades asociadas con las colonias de los perritos de la pradera redujo la productividad vegetal y la riqueza de especies de plantas de las praderas de zacates mixtos al reducir los zacates perennes de estacion fría y el mantillo, incrementando el suelo desnudo y eliminando el "Big sagebrush".

Key Words: Cynomys ludovicianus, vegetation, nutrition, herbivory

\section{Introduction}

Research was funded in part by the Bureau of Land Management Malta Field Office, Montana, and the Montana State University Agriculture Experiment Station, Bozeman.

Correspondence: Carolyn Johnson-Nistler, MS, Dept of Animal and Range Sciences, Room 119 Linfield Hall, Montana State University, Bozeman, MT 59717-2900. Email: carolynjohnson@montana.edu

Manuscript received 14 August 2003; manuscript accepted 23 April 2004.
In 1998, the United States Fish and Wildlife Service received a petition requesting immediate protection of the black-tailed prairie dog (Cynomys ludovicianus) under the Endangered Species Act. The proposed listing heightened controversy surrounding prairie dogs in the west, as it suggested that prairie dogs have "beneficial or neutral effects on livestock forage" (Graber et al 1998). Much of the literature supporting this idea suggests that activities of prairie dogs do not affect standing 
crop biomass (Coppock et al 1983a), increase plant species richness (Bonham and Lerwick 1976; Coppock et al 1983a; Archer et al 1987), and increase plant nutrient content on prairie dog colonies (Coppock et al 1983a).

Examination of research conducted on prairie dog colonies demonstrates that effects of prairie dogs on rangelands are not uniform. Aboveground plant biomass, plant species richness, and cover vary geographically (Coppock et al 1983a; Agnew et al 1986; Archer et al 1987; Weltzin et al 1997; Winter et al 2002). Several factors, including age of colony, location, and climate, may influence impacts of prairie dog colonies on the mixed-grass prairie. Coppock et al (1983a) found that prairie dogs alter their habitat by shifting plant species composition from a warm- and cool-season perennial grass-dominated rangeland to a plant community dominated by shrubs and forbs.

Continuous clipping of vegetation by prairie dogs increases nutrient quality of plants located on colonies (Coppock et al 1983a). It has been suggested that this shift in vegetative composition, structure, and nutrition facilitates bison grazing (Coppock et al 1983b). Although it has been demonstrated that forage nitrogen concentration and percent digestibility may increase in response to grazing compared to vegetation on uncolonized areas, it remains unclear what effect this grazing has on total nutrient standing crop.

Although effects of prairie dogs on vegetation have been examined throughout much of the Great Plains region, little information has come from the mixed-grass prairie in Montana, where cool-season wheatgrasses (Agropyron spp. Gaertn.) are dominant. The objectives of this study were to compare total plant biomass, plant species richness, cover, nutritional differences, and shrub dynamics between prairie dog colonies and adjacent uncolonized sites in Montana.

\section{Study Sites and Methods}

This study was conducted in south Phillips County, located in north central Montana on the northern mixed-grass prairie. The study area was about $24-85 \mathrm{~km}$ south of Malta, Montana (lat $48^{\circ} 22^{\prime} 39^{\prime \prime} \mathrm{N}$, long $107^{\circ} 51^{\prime} 40^{\prime \prime} \mathrm{W}$ ). Land ownership was a mixture of federal, private, and state lands. Prairie dogs occupy about 6500 hectares in Phillips County. Cattle grazed all sites at some time during the year.

Topography varied from flat upland plains to gently sloping hills. Slopes ranged from $0 \%$ to $5 \%$ and occurred on all exposures. Elevations ranged from 610 to $1070 \mathrm{~m}$. Soils have a thin soil surface underlain by hardpan. Permeability is slow. Soils were derived from glacial till and were of the order Aridosol. Soil series that characterize this site include Absher, Elloam, and Thoeny (USDA 1981).

Precipitation averages $28 \mathrm{~cm}$ annually (USDA 1981). Precipitation for 2000 and 2001 was $32 \%$ and $22 \%$ below average, respectively. About $80 \%$ of the precipitation received annually during a normal year falls during the April-September growing season. Winters are cold with a long-term January average of $-13.3^{\circ} \mathrm{C}$. Summers are warm with a long-term July average of $19.2^{\circ} \mathrm{C}$ (USDA 1981). The frost-free growing season averages 112 days and begins mid-May. High winds, blizzards, droughts, and thunderstorms are common in this region (Goetz 1988).
Grasses typical of a mixed-grass prairie dominated the area, but Wyoming big sagebrush (Artemisia tridentata ssp. wyomingensis Beetle and Young) was often common throughout the region. Major grasses included western wheatgrass (Agropyron smithii Rydb.), blue grama (Bouteloua gracilis [HBK] Lag. ex Steud), needle-and-thread (Stipa comata Trin. \& Rupr.), and Sandberg's bluegrass (Poa secunda Presl). Cattle ranching represented the major land use.

Nineteen prairie dog colonies and adjacent uncolonized sites were sampled between 16 June 2000 and 13 August 2000. An additional 21 paired sites were sampled between 9 June 2001 and 27 July 2001 for a total of 40 sites. Colonized sites varied in age from less than 10 years to greater than 50 years of colonization by prairie dogs. Average time since colonization was greater than 20 years. Uncolonized sites were located a minimum of $100 \mathrm{~m}$ from nearest active burrow on the corresponding colonized area. Thirty of the 40 paired sites were codominated by Wyoming big sagebrush at the uncolonized site. Cattle grazed both colonized and uncolonized sites at some time during the year. Sites grazed by cattle before sampling for that year were avoided when possible. Less than $25 \%$ of sites sampled were grazed by cattle before sampling. Study sites were chosen to represent the vegetation typical of that on colonized and uncolonized areas in south Phillips County, Montana. Portions of colonies exhibiting long-term occupation with virtually no vegetation were not sampled. Colonized and uncolonized sites were matched by topography, slope, soil, and elevation to avoid any confounding effects. Because soil is an important factor influencing plant production in our study area, a soil scientist visited about 25 of our sites to ensure that the study was not confounded because of differences in soil.

From a random point within each sampling area, a $30-\mathrm{m}$ north/south line was established using a compass. This line became the center line of the plot. Two additional $30-\mathrm{m}$ lines were established $10 \mathrm{~m}$ east and west of the center line. Thirty $0.25-\mathrm{m}^{2}$ quadrats, one every $3 \mathrm{~m}$, were used to estimate cover and biomass of individual plant species.

A double-sampling method was used for determining standing crop biomass (Wilm 1944) for each plant species. This method consisted of ocular estimation of 30 quadrats per site (2 400 total), and weight determination by species of 9 of these quadrats ( 720 total) that were clipped to ground level. Biomass estimates were made for each species in grams of fresh weight per quadrat (Reich et al 1993). Training to ocularly estimate biomass was performed weekly to achieve desired $r^{2}$ values $(>0.9)$ for major plant species.

Separate linear regressions were developed for dry weight of herbage per unit area as a function of constant dry weight and ocular estimates of fresh weight for each plant species using the GLM (General Linear Model) procedure of SAS (1996). For each individual plant species, weekly regression equations were tested against the seasonal equation. The overall seasonal regression equation was used for $95 \%$ of the plant species since they were not different $(P<0.10)$. Equations were compiled for similar morphological species when the plant species were rare and an inadequate number of estimated and clipped plots were available. Collected plants were dried at $60^{\circ} \mathrm{C}$ for 48 hours before weighing. Dry weight was recorded, and vegetation samples were composited on the basis of vegetative classes. Each plant sample was assigned to one of 
the following groups: cool-season $\left(C_{3}\right)$ grasses, warm-season $\left(\mathrm{C}_{4}\right)$ grasses, standing dead grasses, forbs, or dwarf shrubs. These composites were ground in a Wiley mill to pass a $1-\mathrm{mm}$ screen for subsequent analyses.

Herbaceous understory cover within each quadrat was divided into the following categories: bare ground, live vegetation, litter, rock, lichen, and club moss (Selaginella densa Rydb.). Quadrats that were located on prairie dog mounds, generally void of vegetation, were included in the sample since they were representative of the vegetation in the area, but less than $6 \%$ of the total quadrats sampled on a prairie dog colony were located on mounds. Wyoming big sagebrush (sagebrush) was sampled using three $2 \times 29.4-\mathrm{m}$ belt transects per site. Within these belt transects, average sagebrush percent canopy cover was measured by the line intersection method (Canfield 1941). Density (plants $/ \mathrm{m}^{2}$ ) within these belt transects was measured as well. Sagebrush available winter forage was determined from measurements taken from 30 plants at each site according to Wambolt et al (1994). This conversion represents a conservative estimate of sagebrush biomass since it was used to estimate winter biomass.

Nutritional content of plants was determined using 9 clipped plots per site. Vegetation from the clipped plots was composited on the basis of vegetative class. Vegetation samples were analyzed for dry matter and crude protein (CP) concentration according to AOAC (1995) procedures. In vitro dry matter digestibility (IVDMD) was determined with the Tilley and Terry (1963) procedure, as modified by Moore (Harris 1970). Bovine rumen fluid inoculum from 2 rumen-cannulated animals was composited for IVDMD, which was conducted in triplicate. Neutral detergent fiber (NDF) and acid detergent fiber (ADF) followed the methods of Van Soest et al (1991). All analyses were determined on the basis of the 5 vegetative classes presented above. Crude protein results were combined with biomass data to estimate total standing crude protein for both treatments (CP $[\mathrm{kg} / \mathrm{ha}]=$ standing crop biomass $[\mathrm{kg} / \mathrm{ha}]) \times(\mathrm{CP}[\%])$.

Comparisons were made between colonized and uncolonized areas within the same site for standing crop biomass, species richness, herbaceous understory canopy coverage, total standing crude protein, sagebrush biomass, sagebrush canopy cover, and sagebrush density using paired $t$ tests with 39 degrees of freedom (Steel and Torrie 1980) ( $n=40)$. Due to the lack of plant material necessary to conduct all nutritional analyses, differences between sites in CP, IVDMD, NDF, and ADF were tested using unpaired Student's $t$ tests based on small sample sizes (Conklin 1994).

The experimental unit was individual site. Traditional analysis of variance was not possible as treatments were nested within years and therefore year $\times$ treatment interactions could not be tested. Nineteen colonized and uncolonized sites were paired and sampled in 2000 and 21 colonized and uncolonized sites were paired in 2001 for a total sample size of 40 . Years were combined for analyses. All differences were declared significant when $P<0.05$.

\section{Results and Discussion}

\section{Plant Dynamics}

Total standing crop biomass was more than two times greater $(P<0.001)$ on uncolonized rangeland when compared to
Table 1. Standing crop biomass $(\mathrm{kg} / \mathrm{ha})$ on areas colonized and uncolonized by black-tailed prairie dogs on the mixed-grass prairie of Montana during 2000 and 2001.

\begin{tabular}{lccc}
\hline & Colonized & Uncolonized & SE \\
\hline $\mathrm{C}_{3}$ graminoids (total) & $46.6^{\mathrm{a}}$ & $134^{\mathrm{b}}$ & 7.5 \\
Agropyron smithii & $33.0^{\mathrm{a}}$ & $76.2^{\mathrm{b}}$ & 7.8 \\
Stipa comata & $4.3^{\mathrm{a}}$ & $21.0^{\mathrm{b}}$ & 3.9 \\
Koeleria macrantha & $3.2^{\mathrm{a}}$ & $6.8^{\mathrm{a}}$ & 1.7 \\
Poa secunda & $3.0^{\mathrm{a}}$ & $19.2^{\mathrm{b}}$ & 4.0 \\
Carex filifolia & $2.3^{\mathrm{a}}$ & $6.8^{\mathrm{b}}$ & 1.2 \\
Other $\mathrm{C}_{3}$ graminoids & 0 & 4.0 & 1.6 \\
$\mathrm{C}_{4}$ graminoids (total) & $45.1^{\mathrm{a}}$ & $74.8^{\mathrm{b}}$ & 6.2 \\
Bouteloua gracilis & $39.2^{\mathrm{a}}$ & $71.1^{\mathrm{b}}$ & 8.1 \\
Sporobolus cryptandrus & $4.2^{\mathrm{a}}$ & $0.8^{\mathrm{a}}$ & 2.2 \\
Schedonnardus paniculatus & $1.7^{\mathrm{a}}$ & $2.6^{\mathrm{a}}$ & 1.6 \\
Other C 4 graminoids & 0 & 0.3 & .15 \\
Standing dead grass & $14.5^{\mathrm{a}}$ & $102.2^{\mathrm{b}}$ & 5.7 \\
Forbs (total) & $17.3^{\mathrm{a}}$ & $12.1^{\mathrm{a}}$ & 2.5 \\
Sphaeralcea coccinea & $7.2^{\mathrm{a}}$ & $4.1^{\mathrm{a}}$ & 1.5 \\
Astragalus spp. & $2.2^{\mathrm{a}}$ & $1.6^{\mathrm{a}}$ & 0.9 \\
Antenneria parvifolia & $0.6^{\mathrm{a}}$ & $3.3^{\mathrm{a}}$ & 1.9 \\
Other forbs & 7.3 & 3.1 & 1.2 \\
Dwarf Shrubs (total) & $108.7^{\mathrm{a}}$ & $52.6^{\mathrm{b}}$ & 12.5 \\
Artemisia frigida & $102.6^{\mathrm{a}}$ & $48.6^{\mathrm{a}}$ & 17.2 \\
Ceratoides lanata & $2.2^{\mathrm{a}}$ & $0.9^{\mathrm{a}}$ & 0.9 \\
Gutierrezia sarothrae & $1.4^{\mathrm{a}}$ & $1.8^{\mathrm{a}}$ & 0.7 \\
Other dwart shrubs & 2.5 & $1.3^{\mathrm{a}}$ & 0.8 \\
Artemisia tridentata wyomingensis & $11^{\mathrm{a}}$ & $210^{\mathrm{b}}$ & 2.2 \\
Total & $233.2^{\mathrm{a}}$ & $585.7^{\mathrm{b}}$ & 37.7 \\
\hline
\end{tabular}

$n=40$.

'Available winter forage (Wambolt et al. 1994).

Different superscripts within rows indicate significant differences $(P<0.05)$ from pairwise comparisons.

prairie dog colonies (Table 1). Aboveground standing crop biomass for cool-season $\left(\mathrm{C}_{3}\right)$ grasses, dominated by western wheat grass $(13 \%)$, needle-and-thread $(4 \%)$, and Sandberg's bluegrass $(2 \%)$, was nearly three times greater on uncolonized rangeland. Warm-season $\left(\mathrm{C}_{4}\right)$ grasses, consisting primarily of blue grama, were also greater $(P<0.01)$ on uncolonized rangeland.

Nearly seven times $(P<0.001)$ the amount of standing dead grass was present on uncolonized rangeland when compared to the colonized areas. The increased amount of standing dead biomass that was located on the uncolonized rangeland was due to the clipping of vegetation by prairie dogs on their colonies to increase visibility and facilitate movement (King 1955), thereby greatly decreasing the amount of grasses that reach maturity.

The ratio of $\mathrm{C}_{3}$ to $\mathrm{C}_{4}$ grasses was about $1: 1$ on colonized sites (Table 1). On the adjacent uncolonized rangeland, the ratio was about 2:1 (Table 1). This comparison suggests that prairie dog activity results in a replacement of cool-season grasses with warm-season grasses, similar to the effects of heavy grazing by cattle (Biondini and Manske 1996). In addition, prairie dog colonization often follows intensive grazing and soil disturbance associated with homestead sites 
Table 2. Percent understory cover on areas colonized and uncolonized by black-tailed prairie dogs on the mixed-grass prairie in Montana during 2000 and 2001.

\begin{tabular}{lccc}
\hline & Colonized & Uncolonized & SE \\
\hline Bare ground & $27^{\mathrm{a}}$ & $17^{\mathrm{b}}$ & 1.6 \\
Live herbaceous & & & \\
$\quad$ vegetation & $17^{\mathrm{a}}$ & $18^{\mathrm{a}}$ & 1.5 \\
Litter & $23^{\mathrm{a}}$ & $27^{\mathrm{b}}$ & 1.8 \\
Rock & $15^{\mathrm{a}}$ & $13^{\mathrm{a}}$ & 2.1 \\
Lichen & $3^{\mathrm{a}}$ & $4^{\mathrm{a}}$ & 0.6 \\
Club moss & $15^{\mathrm{a}}$ & $19^{\mathrm{a}}$ & 2.8 \\
\hline
\end{tabular}

$n=40$.

Different superscripts within rows indicate significant differences $(P<0.05)$ from pairwise comparisons.

(Knowles 1986). Prairie dog colonies are often located near stock watering sites or other sources of water (Knowles 1986); therefore, some vegetal removal may be due to a combination of livestock grazing and prairie dog consumption/clipping. Areas historically grazed by cattle have greater proportions of warm-season grasses, shrubs and forbs, which may be indicative of retrogression, a reduction in seral stage, and may affect the long-term production of a site (Fleischner 1994).

There was no difference $(P>0.05)$ in total forb standing crop biomass between colonized and uncolonized sites. However, forbs accounted for $7 \%$ of the total biomass on colonized areas, and only $2 \%$ of the total biomass on uncolonized rangeland. This apparent increase in forb biomass is consistent with research completed in other areas (Collins et al 1984). Forb presence is generally a direct result of rainfall. Forb biomass may have been relatively low because of the low amount of precipitation in south Phillips County during the summers of 2000 and 2001.

More than twice the amount of dwarf shrub standing crop biomass was present on rangeland colonized by prairie dogs throughout the sampling seasons. Fringed sagewort (Artemisia frigida Willd.) was the dominant dwarf shrub, and comprised $94 \%$ of the biomass for that vegetative class (Table 1 ). The increase in dwarf shrub biomass agrees with the findings of Coppock et al (1983a), who reported that over $55 \%$ of the total biomass on an area occupied by prairie dogs in South Dakota consisted of fringed sagewort. Areas with a large percentage of fringed sagewort biomass are associated with rangelands that have been heavily grazed (Spang 1954).

Sagebrush standing crop biomass was much greater $(P<0.001)$ on uncolonized rangeland when compared to the colonized rangeland. There was very little live sagebrush within any colony sampled. It appears that prairie dogs actively remove sagebrush until entire stands have been destroyed. Removal of sagebrush tends to create a more xeric site, making it extremely difficult for sagebrush to re-establish (Lusby 1979). This may lower the overall productivity of a site and plant community.

Our biomass results did not agree with the findings by Coppock et al (1983a) or by Whicker and Detling (1988), who found no difference in standing crop biomass on prairie dog colonies of the mixed-grass prairie when compared to uncolonized areas. The primary reason that our work differed from other research conducted in South Dakota was that we sampled areas that represented at least $70 \%$ of the prairie dog colony, whereas other researchers focused on different zones or age classes within a colony, including younger portions of the prairie dog town and an edge zone (Coppock et al 1983a; Whicker and Detling 1988). Recently colonized areas may not have the same vegetation characteristics that are present on older portions of the colony. An initial spike in plant primary productivity has generally been associated with moderate grazing, regardless of the grazer (McNaughton 1979). This phenomenon is probably no different on prairie dog colonies, where vegetation is constantly being clipped. Recently colonized areas (occupied less than 10 years) may exhibit little difference in aboveground plant biomass, if not slightly higher. Repeated heavy grazing, on the other hand, often results in lower overall plant productivity and a change in seral stage. Areas grazed by prairie dogs for more than 20 years may produce quite different vegetation from that on young prairie dog towns, or "edge" zones. In South Dakota, on a portion of a prairie dog town occupied for more than 26 years, grasses were "virtually eliminated" (Coppock et al 1983a).

Our findings were in agreement with research conducted on the southern mixed-grass prairie of Texas (Weltzin et al 1997). Weltzin et al (1997) concluded that total standing crop biomass was three to four times greater on uncolonized rangeland when compared to the interior of a colonized area. The similarity between these results is probably due to nearly identical sampling procedures at both locations.

Total standing crop biomass was much higher $(P<0.001)$ on uncolonized land when compared to areas colonized by prairie dogs. Warm- and cool-season grass biomass both decreased, whereas dwarf shrub and forb biomass increased with grazing by prairie dogs and cattle. The replacement of $\mathrm{C}_{3}$ grasses and sagebrush with $\mathrm{C}_{4}$ grasses, forbs, and dwarf shrubs suggests that prairie dog activity combined with cattle grazing alters the plant community seral stage.

The decrease in total standing crop biomass may have varying effects on different animal species. This decrease may have a detrimental effect across large landscapes on species needing large amounts of herbaceous cover such as sage grouse (Centrocercus urophasianus) (USDA Soil Conservation Service 1975) or mule deer (Odocoileus hemionus) (Leckenby et al 1982). The increase of bare ground that is characteristic of prairie dog colonies may have a positive effect on animal species that require open spaces with less cover, such as the mountain plover (Charadrius montanus) (Miller and Ceballos 1994) or burrowing owl (Speotyto cunicularius) (MacCracken et al 1985).

Our findings indicate that colonization of rangelands by prairie dogs in the mixed-grass prairie of Montana decreases the number of plant species found at a site. On average, we found 13 plant species on colonized sites and 17 plant species on uncolonized sites $(P<0.05)$. These results disagree with the findings of Archer et al (1987) and Coppock et al (1983a). One factor contributing to this difference might be time since colonization, as plant species richness changes with increased time since prairie dog occupancy (Coppock et al 1983a). The prairie dog colonies that were sampled in South Dakota were younger than most of the prairie dog colonies sampled in our Montana study. Repeated grazing may have similar effects on plant species richness as plant standing crop biomass. Plant 
Table 3. Big sagebrush (Artemisia tridentata ssp. wyomingensis) percent canopy cover and density on areas colonized and uncolonized by black-tailed prairie dogs on the mixed-grass prairie in Montana in 2000 and 2001.

\begin{tabular}{lccc}
\hline & Colonized & Uncolonized & SE \\
\hline Canopy cover $(\%)$ & $0.1^{\mathrm{a}}$ & $7^{\mathrm{b}}$ & 1.70 \\
Density (plants $\left./ \mathrm{m}^{2}\right)$ & $.03^{\mathrm{a}}$ & $1.4^{\mathrm{b}}$ & 0.06 \\
\hline
\end{tabular}

$n=40$.

Different superscripts within rows indicate significant differences $(P<0.05)$ from pairwise comparisons.

species richness may increase initially after immediate grazing pressure, but may decrease in response to long-term grazing pressure (Fleischner 1994).

Bare ground was $10 \%$ greater $(P<0.01)$ within the colonized interior of a prairie dog colony when compared to the adjacent uncolonized rangeland. Live herbaceous vegetative cover was similar $(P>0.05)$ between paired colonized and uncolonized sites (Table 2). Percent litter was greater $(P<0.01)$ on the uncolonized rangeland when compared to the colonized region. Rock, lichen, and club moss cover was similar $(P>0.05)$ between colonized and uncolonized areas.

Winter et al (2002) concluded that vegetative cover and bare ground was not different between colonized and uncolonized areas on the short-grass prairie of Kansas and Colorado. These findings are probably due to the mat-forming perennial grasses such as blue grama and buffalograss (Buchloe dactyloides (Nutt.) Engelm.). They further concluded that these plants are well adapted to herbivory by prairie dogs.

The decrease in percent litter cover on a prairie dog town in this study is directly related to the loss of standing dead and organic matter on a prairie dog colony. Percent rock, lichen, and club moss are primarily a function of site, and would not be expected to change between treatments as soils were matched as closely as possible for all paired colonized/uncolonized sites.

The decrease in litter and increase in bare soil may result in a warmer, drier microenvironment (Archer et al 1987). Reductions in live and dead plant biomass and litter could result in a decrease in the interception of precipitation by vegetation. This increase in bare soil may also lead to an increase in evaporative losses. Therefore, water availability in the first few centimeters of soil will tend to be lower on heavily grazed sites, even after a precipitation event (Whicker and Detling 1988).

Sagebrush canopy cover and density were greater $(P<0.001)$ on uncolonized rangeland compared to colonized areas (Table 3). Effects of prairie dogs on sagebrush colonies had not previously been quantified in the scientific literature, although prairie dogs have been documented as a control agent for mesquite (Prosopis glandulosa Torr.) in the southern mixedgrass prairie (Miller 1991).

Our results suggest that prairie dogs actively eliminate and destroy sagebrush during their colonization process. Long-term productivity of these sites may be diminished because of this loss of sagebrush. Sagebrush creates a microclimate, which allows other plants to grow, and retains moisture in the soil, which can be taken up by other plants (Peterson 1995). Sagebrush may take up to 50 years to recover after stand removal due to fire (Blaisdell et al 1982; Bunting et al 1987).
Table 4. Crude protein, standing crude protein, IVDMD, NDF, and ADF on areas colonized and uncolonized by black-tailed prairie dogs on the mixed-grass prairie in Montana during 2000 and 2001.

\begin{tabular}{|c|c|c|c|c|c|}
\hline & \multicolumn{5}{|c|}{ Crude protein } \\
\hline & \multicolumn{2}{|c|}{ Colonized } & \multicolumn{2}{|c|}{ Uncolonized } & \multirow[b]{2}{*}{ SE } \\
\hline & $n$ & $\mathrm{CP}(\%)$ & $n$ & $\mathrm{CP}(\%)$ & \\
\hline $\mathrm{C}_{3}$ grass & 28 & $11.5^{\mathrm{a}}$ & 40 & $9.4^{\mathrm{b}}$ & 0.5 \\
\hline $\mathrm{C}_{4}$ grass & 34 & $10.1^{\mathrm{a}}$ & 35 & $8.6^{\mathrm{b}}$ & 0.3 \\
\hline Standing dead grass & 17 & $7.1^{\mathrm{a}}$ & 38 & $5.1^{b}$ & 0.4 \\
\hline Forbs & 25 & $14.0^{\mathrm{a}}$ & 22 & $12.9^{\mathrm{a}}$ & 0.8 \\
\hline \multirow[t]{3}{*}{ Dwart shrub } & 30 & $11.9^{\mathrm{a}}$ & 32 & $10.6^{b}$ & 0.3 \\
\hline & \multicolumn{5}{|c|}{ Standing crude protein $(\mathrm{kg} / \mathrm{ha})^{1} n=40$} \\
\hline & \multicolumn{2}{|c|}{ Colonized } & \multicolumn{2}{|c|}{ Uncolonized } & SE \\
\hline $\mathrm{C}_{3}$ grass & \multicolumn{2}{|c|}{$5.5^{\mathrm{a}}$} & \multicolumn{2}{|c|}{$12.7^{\mathrm{b}}$} & 0.80 \\
\hline $\mathrm{C}_{4}$ grass & \multicolumn{2}{|c|}{$4.8^{\mathrm{a}}$} & \multicolumn{2}{|c|}{$6.1^{\mathrm{a}}$} & 0.61 \\
\hline Standing dead grass & \multicolumn{2}{|c|}{$1.1^{\mathrm{a}}$} & \multicolumn{2}{|c|}{$5.1^{b}$} & 0.32 \\
\hline Forbs & \multicolumn{2}{|c|}{$2.4^{\mathrm{a}}$} & \multicolumn{2}{|c|}{$1.5^{\mathrm{a}}$} & 0.37 \\
\hline Dwarf shrub & \multicolumn{2}{|c|}{$12.8^{\mathrm{a}}$} & \multicolumn{2}{|c|}{$5.8^{b}$} & 1.49 \\
\hline \multirow[t]{4}{*}{ Total } & & $6.6^{\mathrm{a}}$ & & & 1.86 \\
\hline & \multicolumn{5}{|c|}{ IVDMD } \\
\hline & \multicolumn{2}{|c|}{ Colonized } & \multicolumn{2}{|c|}{ Uncolonized } & \\
\hline & $n$ & IVDMD (\%) & $n$ & $\operatorname{IVDMD}(\%)$ & SE \\
\hline $\mathrm{C}_{3}$ grass & 24 & $41.2^{\mathrm{a}}$ & 38 & $39.6^{\mathrm{a}}$ & 2.2 \\
\hline $\mathrm{C}_{4}$ grass & 23 & $29.2^{\mathrm{a}}$ & 32 & $28.0^{\mathrm{a}}$ & 1.7 \\
\hline Standing dead grass & 8 & $29.7^{\mathrm{a}}$ & 37 & $24.6^{\mathrm{a}}$ & 2.2 \\
\hline Forbs & 20 & $46.6^{\mathrm{a}}$ & 10 & $42.7^{\mathrm{a}}$ & 3.3 \\
\hline \multirow[t]{4}{*}{ Dwarf shrub } & 30 & $31.2^{\mathrm{a}}$ & 15 & $25.8^{\mathrm{b}}$ & 2.0 \\
\hline & \multicolumn{5}{|c|}{ NDF } \\
\hline & \multicolumn{2}{|c|}{ Colonized } & \multicolumn{2}{|c|}{ Uncolonized } & \\
\hline & $n$ & NDF $(\%)$ & $n$ & NDF $(\%)$ & SE \\
\hline $\mathrm{C}_{3}$ grass & 27 & $63.4^{\mathrm{a}}$ & 40 & $63.3^{\mathrm{a}}$ & 0.74 \\
\hline $\mathrm{C}_{4}$ grass & 25 & $67.6^{\mathrm{a}}$ & 34 & $67.5^{\mathrm{a}}$ & 0.58 \\
\hline Standing dead grass & 8 & $65.1^{\mathrm{a}}$ & 38 & $68.0^{\mathrm{a}}$ & 0.90 \\
\hline Forbs & 15 & $44.0^{\mathrm{a}}$ & 7 & $41.1^{\mathrm{a}}$ & 2.55 \\
\hline Dwarf shrub & 30 & $48.0^{\mathrm{a}}$ & 11 & $46.7^{\mathrm{a}}$ & 0.83 \\
\hline & & & ADF & & \\
\hline & & lonized & & lonized & \\
\hline & $n$ & ADF (\%) & $n$ & ADF (\%) & SE \\
\hline $\mathrm{C}_{3}$ grass & 27 & $31.7^{\mathrm{a}}$ & 40 & $33.1^{\mathrm{a}}$ & 0.67 \\
\hline $\mathrm{C}_{4}$ grass & 25 & $32.7^{\mathrm{a}}$ & 34 & $32.2^{\mathrm{a}}$ & 0.54 \\
\hline Standing dead grass & 8 & $35.7^{\mathrm{a}}$ & 38 & $40.6^{b}$ & 0.84 \\
\hline Forbs & 15 & $27.8^{\mathrm{a}}$ & 7 & $26.2^{\mathrm{a}}$ & 2.26 \\
\hline Dwarf shrub & 30 & $34.3^{\mathrm{a}}$ & 11 & $32.2^{\mathrm{a}}$ & 0.84 \\
\hline
\end{tabular}

Different superscripts within rows indicate significant differences $(P<0.05)$ from pairwise comparisons.

${ }^{1} \mathrm{CP}(\mathrm{kg} / \mathrm{ha})$ indicates standing crop biomass $(\mathrm{kg} / \mathrm{ha}) \times \mathrm{CP}(\%)$; IVDMD, in vitro $\mathrm{dry}$ matter digestibility; NDF, neutral detergent fiber; ADF, acid detergent fiber.

The removal of sagebrush by prairie dogs, however, is quite different from that by fire. Immediately after fire has swept through an area, organic matter is deposited directly back into the soil. The seedstock and rootstock persist below ground. 
After removal because of the activities from prairie dogs, the seed and rootstock have been depleted, which may make sagebrush recovery difficult. For example, there are still very few signs of sagebrush recovery in an area in Phillips County where prairie dogs were poisoned nearly 50 years ago. The full extent of the impact of prairie dogs on sagebrush requires further examination, although it appears that areas colonized for long periods of time will take even longer to fully recover.

If the goal of land managers is to restore native sagebrush communities, restoration of these rangelands may be difficult without external inputs. Recovery of these sites to predisturbance conditions may be especially slow because of the low amounts of precipitation Phillips County receives annually.

\section{Nutrient Dynamics}

$\mathrm{CP}$ of all vegetative classes was greater $(P<0.05)$ on colonized areas when compared to uncolonized rangelands, with the exception of forbs, which contained similar concentrations of crude protein $(P>0.10)$ for both treatments (Table 4$)$. Forb production increased immediately after a precipitation event in nearly equal proportions on all sites. These findings are in agreement with Coppock et al (1983a), who reported higher crude protein concentrations within areas colonized by prairie dogs when compared to uncolonized rangelands in the mixedgrass prairie of South Dakota. Results were not expected to differ, because plants that are constantly grazed usually have comparatively low proportions of structural carbohydrates and are less mature, thereby increasing the protein value, compared to areas that are grazed lightly (Huston and Pinchak 1991).

Total standing crude protein $(\mathrm{kg} / \mathrm{ha}$ ) was determined for each vegetative class (Table 4 ). Total standing crude protein yield was $17 \%$ greater $(P<0.05)$ on uncolonized rangeland when compared to the interior of a prairie dog colony. These results do not include any contribution of sagebrush to total standing crop protein. Had sagebrush been included, total standing crude protein off prairie dog colonies would increase greatly, whereas that on prairie dog colonies would not change substantially.

$\mathrm{C}_{3}$ grasses accounted for $41 \%$ of the total standing crude protein available off a prairie dog colony, while making up only $21 \%$ of the total standing crude protein located on a prairie dog colony. This difference represents a $130 \%$ decrease in the total amount of crude protein available ( $\mathrm{kg} / \mathrm{ha}$ ) from cool-season grasses on a prairie dog town when compared to uncolonized rangeland. This decrease in standing crop crude protein of coolseason grasses may be detrimental to cattle, which have been shown to preferentially select for cool-season grasses where available (Uresk 1986).

$\mathrm{C}_{4}$ grasses on prairie dog colonies showed no difference $(P>0.10)$ in total crude protein when compared to uncolonized areas. This comparison indicates that the activities of prairie dogs, when grazed with cattle, may not have significant impacts on the total amount of standing crop protein available from warm-season grasses.

Nearly five times the amount $(P<0.05)$ of total standing crude protein from standing dead grass was located on uncolonized rangeland when compared to colonized areas. Although standing dead grass comprised only $4 \%$ of the total standing crude protein available on colonized areas, it ac- counted for $16 \%$ of the total standing crude protein located on uncolonized rangelands. Cattle have been shown to prefer plants with lower fiber content, which would indicate that they might avoid areas with high amounts of standing dead grass. However, Senft et al. (1985) reported the highest community preference correlation between standing nitrogen and preferred plant species. If this is correct, the high amounts of crude protein contributed by standing dead grass to the total amount of crude protein may have some benefits to livestock grazing, especially since the majority of standing dead material on uncolonized rangelands was comprised of preferred grass species. The amount of plant material available on uncolonized rangelands becomes particularly important during fall and winter, when new green growth is lacking.

There was no difference $(P>0.05)$ between available standing crude protein from forbs in either treatment. However, nearly twice the amount of total standing crude protein on a percent basis was available from the forb component on a prairie dog town when compared to the adjacent uncolonized rangeland. Whereas forbs accounted for $5 \%$ of the total amount of standing crude protein on uncolonized rangeland, the forb component comprised $9 \%$ of the total standing crude protein on a prairie dog town.

Dwarf shrubs accounted for $120 \%$ more standing crude protein on colonized areas than uncolonized rangelands, and comprised nearly $50 \%$ of the total available crude protein on colonized areas (Table 4). The dwarf shrub component comprised about $20 \%$ of the total available nitrogen off prairie dog colonies. Fringed sagewort was the dominant dwarf shrub at all sites. Fringed sagewort is a highly unpalatable and undesirable forage for many ungulates, including cattle (Spang 1954).

There was a greater amount of total forage available from uncolonized rangelands when compared to colonized areas. Because the majority $(50 \%)$ of total forage on a prairie dog colony comes from fringed sagewort, which cattle tend to avoid, and the majority $(40 \%)$ of total forage on uncolonized rangeland comes from cool-season grasses, which cattle tend to prefer (Rauzi 1982), cattle would be just as likely to graze off a prairie dog colony as on a colony. Therefore, if preferred species continued to be grazed, the grazing animal will consume more total crude protein at uncolonized areas, because of the higher concentration of palatable species.

Coppock et al (1983b) demonstrated that bison exhibited strong selection for prairie dog colonies during midsummer at Wind Cave National Park, South Dakota. They reported that it is nutritionally advantageous for bison to graze on prairie dog colonies because of increased CP and increased digestibility. Coppock et al (1983b) concluded that prairie dogs facilitate bison habitat selection by causing a broad array of structural, compositional, and nutritional changes in the vegetation. This "facilitative" idea has been applied to cattle as well (Long 1998; Guenther 2000). Others, however, indicate that grazing ungulates do not exhibit "nutritional wisdom" and select grazing sites on the basis of a variety of factors (Senft et al 1985; Stuth 1991; Bailey et al 1996), including large amounts of available palatable species (Senft et al 1985). Therefore, it is unlikely that changing $\mathrm{CP}$ alone would facilitate large ungulate grazing on prairie dog colonies, with decreased amounts of standing crude protein and perennial grasses, coupled with an increase of unpalatable dwarf shrubs. 
On the short-grass steppe of Colorado, overall cattle use on prairie dog colonies was shown to be random (Guenther 2000). Although cattle exhibited a slight selection for prairie dog colonies during early summer, and slight avoidance during late summer, cattle were observed using prairie dog colonies in proportion to their availability within a pasture throughout the season (Guenther 2000). Although prairie dog colonies may not be preferred grazing patches, cattle can utilize them at certain times of the year. During May and June, when forbs are abundant, cattle use on prairie dog towns may increase, whereas use will probably decrease from July through October, when forage within prairie dog colonies is limiting. For example, on the basis of casual observations during the summers of 2000 and 2001, of 604 cow/calf pairs observed grazing on allotments that contained prairie dog colonies, nearly $75 \%$ were grazing uncolonized areas in Phillips County, Montana.

Further examination of the Coppock et al (1983b) data suggests that there are times during the year when prairie dog colonies are not preferred grazing locations. These findings, coupled with our research in Montana, may indicate that prairie dogs might not facilitate grazing by cattle, although this hypothesis was not tested by our research.

IVDMD was determined for all vegetative classes. Average IVDMD was not different $(P>0.05)$ for any vegetative classes with the exception of dwarf shrubs, which were higher $(P<0.05)$ on colonized rangeland when compared to offcolony rangelands (Table 4). Findings were in accordance with research conducted in South Dakota. Coppock et al (1983a) found slightly higher percent digestibility in areas recently colonized by prairie dogs. Their study also reported higher percent digestibility of cool-season $\left(\mathrm{C}_{3}\right)$ grasses over warmseason grasses $\left(\mathrm{C}_{4}\right)$ in all areas, which was similar to our findings.

Areas heavily grazed by cattle have also been shown to have slightly higher digestibility than areas that have been moderately grazed. Heitschmidt et al (1989) reported 47\% IVDMD in an area that had been moderately grazed by cattle, whereas an area heavily grazed had a reported IVDMD of $49 \%$. Plants that are constantly being grazed, regardless of the herbivore, usually exhibit less lignification. This results in greater digestibility.

NDF was not different for any vegetative classes between colonized areas and adjacent uncolonized areas (Table 4). It appears that activities of prairie dogs are not reducing hemicellulose, cellulose, and lignin fractions within plant communities. The ADF concentrations were similar $(P>0.05)$ across all vegetative classes with the exception of standing dead grass, which was higher $(P<0.05)$ on uncolonized rangeland when compared to colonized rangeland (Table 4). With the exception of standing dead grass, there were no differences $(P>0.05)$ in the amounts of fiber contained in vegetative classes between vegetation located on prairie dog colonies and vegetation located on uncolonized rangelands.

Prairie dog colonies in Montana were characterized by an increased presence of warm-season grasses, forbs, and dwarf shrubs, whereas off-colony sites were characterized by a dominance of cool-season grasses. This replacement of cool-season perennial grasses by warm-season grasses, forbs, and dwarf shrubs on a colonized area indicates that the activities of prairie dogs, when grazed with cattle, alter the plant species composition of the areas they occupy.

\section{Conclusions}

Areas occupied by black-tailed prairie dogs in eastern Montana's mixed-grass prairie are characterized by a decrease in standing crop biomass, plant species richness, litter, standing crop crude protein, big sagebrush canopy cover and density, and an increase in bare ground and CP. Activities of prairie dogs in Montana result in a dramatic shift in vegetal composition in areas they occupy.

An increase in grazing pressure is often associated with a reduction in seral stage. When this grazing pressure is reduced or removed, the rate of succession to a higher seral stage depends on the extent to which soils, seedbank, and vegetative regeneration potential of the vegetation has been modified. When one group of plants has been displaced by another as a result of heavy disturbance, the new assemblage may be longlived and persistent (Archer and Smeins 1991). The changes associated with the removal of sagebrush indicate that these rangelands have crossed a threshold that may be difficult to overcome without external inputs. Recovery of these sites to predisturbance conditions may be slow because of the low amounts of precipitation Phillips County receives annually.

The unique patches occupied by prairie dogs create an ideal environment for mountain plovers (Miller and Ceballos 1994), burrowing owls (MacCracken et al 1985), and black-footed ferrets (Mustela nigripes) (Flath and Clark 1986). Although these fauna may be attracted to prairie dog colonies because of lack of vegetative cover, it also follows that species that depend on large amounts of herbaceous cover, especially those associated with a sagebrush habitat such as sage grouse or mule deer, may not be as successful in large landscape areas dominated by prairie dogs.

\section{Acknowledgment}

Additional thanks to the Veseth and Veseth Livestock Company, whose cooperation made completion of fieldwork possible.

\section{Literature Cited}

Agnew, W., D. W. UreSk, and R. M. Hansen. 1986. Flora and fauna associated with prairie dog colonies and adjacent ungrazed mixed-grass prairie in Western South Dakota. Journal of Range Management 39:135-139.

AOAC. 1995. Official Methods of Analysis. 16th ed. Washington DC: Association of Official Analytical Chemists. p. 4.1-4.5.

Archer, S., M. G. Garrett, and J. K. Detling. 1987. Rates of vegetation change associated with prairie dog grazing. Vegetatio 72:159-166.

Archer, S., And F. E. Smeins. 1991. Ecosystem-level process. In: R. K. Heitschmidt and J. W. Stuth [eds.]. Grazing management: An ecological perspective. Portland, OR: Timber Press. p 109-140.

Bailey, D. W., J. E. Gross, E. A. LacA, L. R. Rittenhouse, M. B. Coughenour, D. M. SwIF, AND P. L. Sims. 1996. Mechanisms that result in large herbivore grazing distribution patterns. Journal of Range Management 49:386-400.

BIONDINI, M. E., AND L. MANSKE. 1996. Grazing frequency and ecosystem processes in a northern mixed-grass prairie. Ecological Applications 6:239-256.

Blaisdell, J. P., R. B. Murray, and E. D. McArthur. 1982. Managing intermountain rangelands--sagebrush-grass ranges. USDA Forest Service General Technology Report INT-134.

Bonham, C. D., AND A. LeRwick. 1976. Vegetation changes induced by prairie dogs on shortgrass prairie. Journal of Range Management 29:221-229.

Bunting, S. C., B. M. KiLgORE, AND C. L. Bushey. 1987. Guidelines for prescribed burning sagebrush-grass rangelands in the northern Great Basin. USDA Forest Service General Technology Report INT-231. 
CAmfield, R. H. 1941. Application of the line interception method in sampling range vegetation. Journal of Forestry 39:388-394.

Collins, A. R., J. P. Workman, and D. W. Uresk. 1984. An economic analysis of black-tailed prairie dog control. Journal of Range Management 37:358-361.

ConkLIN, N. L. 1994. Tannin and in vitro digestibility of tropical browse: Predictive equations. Journal of Range Management 47:398-404.

Coppock, D. L., J. K. Detling, J. E. ElLIS, and M. I. Dyer. 1983a. Plant-herbivore interactions in an American mixed-grass prairie. I. Effects of black-tailed prairie dogs on intraseasonal aboveground plant biomass and nutrient dynamics. Oceologia 56:1-9.

Coppock, D. L., J. K. Detling, J. E. Ellis, and M. I. Dyer. 1983b. Plant-herbivore interactions in an American mixed-grass prairie. II. Responses of bison to modification of vegetation by prairie dogs. Oceologia 56:10-15.

FLATH, D. L., AND T. W. CLARK. 1986. Historic status of black-footed ferret habitat in Montana. Great Basin Naturalist Memoirs 8:63-71.

FLeISCHnER, T. L. 1994. Ecological costs of livestock grazing in western North America. Conservation Biology 8:629-644.

Goetz, H. 1988. Rangelands of the Northern Great Plains-An overview. In: R. S. White and R. E. Short [eds.]. Achieving Efficient Use of Rangeland Resources; Fort Keogh Research Symposium; September 1987; Mt. Agnic. Exp. Stat. Miles City, MT: p 4-10.

Graber, K., T. France, and S. Miller. 1998. Petition for rule listing the black-tailed prairie dog (Cynomys ludovicianus) as threatened. Federal Register 64:1442414428.

Guenther, D. A. 2000. Cattle use of prairie dog towns on the shortgrass steppe of Colorado [thesis]. Fort Collins, CO: Colorado State University. 56 p.

HARRIS, L. E. 1970. in vitro dry matter or organic matter digestion (Moore modification of Tilley and Terry technique). In: Nutrition Research Techniques for Domestic and Wild Animals. Vol. 1. p 5051-5053. Utah State University, Logan.

Heitschmidt, R. K., S. L. Dowhower, W. E. Pinchak, ano K. Canon. 1989. Effects of stocking rate on quantity and quality of available forage in a southern mixedgrass prairie. Journal of Range Management 42:468-471.

Huston, J. E., and W. E. Pinchak. 1991. Range animal nutrition. In: R. K. Heitschmidt and J.W. Stuth [eds.]. Grazing management: An ecological perspective. Portland, OR: Timber Press. Chapter 2.

King, J. A. 1955. Social Behavior, Social Organization, and Population Dynamics in a Black-Tailed Prairie Dog Town in the Black Hills of South Dakota. Contributions from the Laboratory in Vertebrate Biology, University of Michigan, No. 67.

KNowles, C. J. 1986. Some relationships of black-tailed prairie dogs to livestock grazing. Great Basin Naturalist 46:198-203.

Leckenby, D. A., D. P. Sheehy, C. H. Nellis, R. J. Scherzinger, I. D. Luman, W. Elmore, J. C. Lemos, L. Doughty, ano C. E. Trainer. 1982. Wildlife habitats in managed rangelands-The great basin of southeastern Oregon-mule deer. USDA Forest Service General Technology Report PNW-139.

LoNG, M. E. 1998. The vanishing prairie dog. National Geographic 193:116-130.

LuSBY, G. C. 1979. Effects of converting sagebrush cover to grass on the hydrology of small watersheds at Boco Mountain, Colorado. Geological Survey Water Supply Paper 1532-J. Washington, DC: U.S. Government Printing Office.
MacCracken, J. G., D. W. Uresk, and R. M. Hansen. 1985. Vegetation and soils of burrowing owl nest sites in Conata Basin, South Dakota. The Condor 87:152154.

McNaughton, S. J. 1979. Grazing as an optimization process: Grass-ungulate relationships in the Serengeti. American Naturalist 113:691-703.

Miller, B., and G. Ceballos. 1994. The prairie dog and biotic diversity. Conservation Biology 8:677-681.

MilleR, J. A. 1991. Suffering from a prairie dog shortage. Bioscience 41:753.

Peterson, J. G. 1995. Ecological implications of sagebrush manipulation. Helena, MT: Montana Fish, Wildlife and Parks Bulletin W-101-R-2.

Rauzl, F. 1982. Seasonal variations in protein and mineral content of fringed sagewort (Artemisia frigida). Journal of Range Management 35:679-680.

Reich, R. M., C. D. Bonham, And K. K. Remington. 1993. Double sampling revisited. Journal of Range Management 46:88-90.

SAS InStitute. 1996. SAS/STAT User's guide, version 6.11. Carey, NC: SAS Institute.

Senft, R. L., L. R. Rittenhouse, and A. G. Woodmansee. 1985. Factors influencing patterns of cattle grazing behavior on shortgrass steppe. Journal of Range Management 38:82-87.

Spang, E. F. 1954. Utilization of fringed sagewort on a winter sheep range. Journal of Range Management 7:73-74.

Steel, R. G. D., And J. H. TorRie. 1980. Principles and procedures of statistics. 2nd ed. New York, NY: McGraw-Hill. 633 p.

Stuth, J. W. 1991. Foraging behavior. In: R. K. Heitschmidt and J. W. Stuth [eds.]. Grazing management: An ecological perspective. Portland, OR: Timber Press. Chapter 3.

Tilley, J. M. A., And R. A. Terry. 1963. A two stage technique for in vitro digestion of forage crops. Journal of the British Grassland Society 18:104-111.

URESK, D. W. 1986. Food habits of cattle on mixed-grass prairie of the Northern Great Plains. Prairie Naturalist 18:211-218.

USDA. 1981. Technical Guide. Section II-E-8. USDA-SCS-MT. August 1981.

USDA Soll Conservation Service. 1975. Habitat management for sage grouse. Bozeman, MT: MT. 7-N-19000-64.

Van Soest, P. J., J. B. Robertson, and B. A. Lewis. 1991. Methods for dietary fiber, neutral detergent fiber, and nonstarch polysaccharides in relation to animal nutrition. Journal of Dairy Science 74:3583-3597.

Wambolt, C. L., W. H. Creamer, and R. J. Rossi. 1994. Predicting big sagebrush winter forage by subspecies and browse form class. Journal of Range Management 47:231-234.

Weltzin, J. F., S. L. Dowhower, and R. K. HeitSchmidt. 1997. Prairie dog effects on plant community structure in southern mixed-grass prairie. The Southwestern Naturalist 42:251-258.

Whicker, A. D., Ano J. K. Detuing. 1988. Ecological consequences of prairie dog disturbances. Bioscience 38:11.

WILM, H. G. 1944. Estimating forage yield by the double-sampling method. Journal of the American Society of Agronomy 36:194-203.

Winter, S. L., J. F. Cully, JR., Ano J. S. Pontius. 2002. Vegetation of prairie dog colonies and non-colonized shortgrass prairie. Journal of Range Management 55:502-508. 